\title{
Ectopic Atrial Rhythm by ECG Finding
}

National Cancer Institute

\section{Source}

National Cancer Institute. Ectopic Atrial Rhythm by ECG Finding. NCI Thesaurus. Code C62245.

An electrocardiographic finding of a regular atrial rhythm with atrial rate of less than 101 beats per minute which does not originate in the sinus node, and which is characterized by $\mathrm{P}$ waves whose morphology differs from the $\mathrm{P}$ wave morphology during sinus rhythm. (CDISC) 